CZASOPISMO INŻYNIERII LĄDOWEJ, ŚRODOWISKA I ARCHITEKTURY

JOURNAL OF CIVIL ENGINEERING, ENVIRONMENT AND ARCHITECTURE

JCEEA, t. XXXIV, z. 64 (3/II/17), lipiec-wrzesień 2017, s. 419-428, DOI:10.7862/rb.2017.183

Krzysztof WILK ${ }^{1}$

\title{
GEOTECHNICZNE UWARUNKOWANIA POSADOWIENIA OBIEKTÓW BUDOWLANYCH NA TERENIE RZESZOWA
}

\begin{abstract}
W artykule opisane zostały główne formy morfologiczne występujące na terenie Rzeszowa, tj. Pogórze Dynowskie, Podgórze Rzeszowskie oraz Pradolinę Podkarpacką. Wskazano na różnice $\mathrm{w}$ budowie podłoża gruntowego na każdym $\mathrm{z}$ tych obszarów. Opisane zostały również warunki hydrologiczne na terenie miasta oraz ich zmiany na przestrzeni czasu, mające wpływ na geotechniczne warunki posadowienia obiektów. W pracy przedstawiono naturalne zagrożenia wynikające ze specyficznej budowy podłoża gruntowego, cechującej się swego rodzaju regionalizmem. Lokalne czynniki warunkujące właściwości geotechniczne gruntu powinny być uwzględnione na etapie rozpoznania podłoża na cele budowlane.
\end{abstract}

\begin{abstract}
Słowa kluczowe: podłoże gruntowe, warunki gruntowo-wodne, Podgórze Rzeszowskie, Pradolina Podkarpacka, pyły lessopodobne, grunty madowe, zagrożenia geotechniczne
\end{abstract}

\section{Wprowadzenie}

Rozwój Rzeszowa jako dominującego ośrodka administracyjnego, akademickiego i gospodarczego, a także węzła komunikacyjnego na terenie południowo-wschodniej Polski cały czas potwierdzają liczne inwestycje infrastrukturalne i mieszkaniowe. Należy jednak zwrócić uwagę na fakt, iż warunki geotechniczne na obszarze miasta są często niesprzyjające postępującemu procesowi urbanizacji. Nie przekreślają one co prawda planów inwestycyjnych, jednak mogą stanowić ich istotne skomplikowanie.

Przy obecnych możliwościach technicznych posadowienie obiektów budowlanych w niekorzystnych warunkach gruntowych nie jest przeszkodą nie do pokonania. Wymaga jednak zastosowania zaawansowanych i kosztownych rozwiązań fundamentowych. Wiąże się to również z koniecznością dokładniejszego rozpoznania budowy podłoża oraz szczegółowego określenia właściwości grun-

\footnotetext{
${ }^{1}$ Krzysztof Wilk, Politechnika Rzeszowska, Zakład Geodezji i Geotechniki im. Kaspra Weigla, ul. Poznańska 2, 35-959 Rzeszów; tel.: 17865 1006; e-mail: kwilk@ prz.edu.pl
} 
tów je tworzących. Wymaga to odpowiednio szerokiej wiedzy popartej doświadczeniem inżynierskim zarówno od osób przygotowujących, jak i później realizujących inwestycje.

Wspomniane umiejętności i kompetencje personalne są niezbędne także przy realizacji przebudowy lub remontu obiektów już istniejących. Trudności w tym zakresie pogłębia fakt, że posadowienie budowli wznoszonych w XIX lub na początku XX wieku odbywało się w oparciu o wiedzę geotechniczną, która dopiero później zaczęła swój dynamiczny rozwój. Nie oznacza to stosowania wcześniej błędnych rozwiązań technicznych, lecz innego podejścia do pojawiających się problemów inżynierskich. Podejścia, które może zaskakiwać współczesnych inżynierów. Nie były to rozwiązania gorsze, jednak z pewnością inne niż obecnie preferowane - związane to było z niedoskonałościami ówczesnych technik fundamentowania obiektów.

\section{Główne obszary i typowe formy geomorfologiczne na terenie miasta}

Rzeszów położony jest na styku dwóch podstawowych jednostek geologicznych Zewnętrznych Karpat Zachodnich i Zapadliska Przedkarpackiego. W odniesieniu do bardziej szczegółowego podziału geograficznego należy wyodrębnić Pogórze Dynowskie w obszarze pasma Karpat oraz Podgórze (Przedgórze) Rzeszowskie i Pradolinę Podkarpacką wydzielone w ramach Zapadliska Przedkarpackiego [1,2].

Karpaty Zewnętrzne w formie Płaszczowiny Skolskiej mają budowę fliszową, tzn. zbudowane są z wypiętrzonych wskutek ruchów górotwórczych naprzemianległych warstw osadów morskich. Osady takie, o zróżnicowanym uziarnieniu powstały wskutek zmieniających się w czasie warunków sedymentacyjnych i po przejściu różnych form diagenezy utworzyły warstwy skał osadowych: piaskowców, iłowców, mułowców, zlepieńców itd.

Trzeciorzędowe podłoże Zapadliska Przedkarpackiego tworzą powstałe w miocenie iły serii krakowieckiej. Są to również osady morskie, powstałe jednak znacznie później, a ich przedstawicielami są iły i iłołupki z pylastymi i piaszczystymi przewarstwieniami. Iły krakowieckie ze względu na głębokość zalegania mogą stanowić oparcie jedynie dla fundamentowania pośredniego. Posadowienie bezpośrednie możliwe jest na utworach przypowierzchniowych powstałych w czwartorzędzie, które zostaną opisane w dalszej części pracy.

\subsection{Pogórze Dynowskie}

Pogórze Dynowskie obejmuje jedynie niewielką południowo-wschodnią część Rzeszowa - fragmenty osiedli Biała, Zalesie i Słocina. Rzeźba tej części miasta jest zróżnicowana, a bazę podłoża gruntowego stanowi flisz karpacki i różne jego utwory zwietrzelinowe oraz deluwialne. Są nimi najczęściej grunty 
mało i średnio spoiste, niekiedy zwięzło spoiste, natomiast bardzo rzadko formy niespoiste.

Zalegające powierzchniowo, przekształcone utwory fliszowe to grunty nieskonsolidowane o przeciętnej nośności. Jednak z uwagi na zróżnicowanie morfologiczne terenu, pofałdowany i pochylony układ warstw podłoża skalnego, mogą wystąpić zagrożenia ruchami masowymi. Istotne znaczenie dla posadowienia obiektów budowlanych na takim podłożu mogą mieć warunki hydrologiczne - przepływ wód gruntowych i okresowe zmiany zawilgocenia spowodowane opadami atmosferycznymi.

\subsection{Podgórze Rzeszowskie}

Podgórze Rzeszowskie to południowa, granicząca z Karpatami część Zapadliska Przedkarpackiego. Tworzą je wzniesienia zbudowane z czwartorzędowych gruntów pochodzenia eolicznego - lessów. Te nanoszone i deponowane przez wiatr pyły i pyły piaszczyste obecnie w znacznej części zatraciły swoją makroporowatą strukturę. Nie mają już typowo zapadowych właściwości, w związku z czym w odniesieniu do tego podłoża należy raczej używać sformułowań o gruntach lessopodobnych. Podłoże takie buduje przede wszystkim zachodnią, południowo-zachodnią i wschodnią część miasta - osiedla Przybyszówka, Staroniwa, Zwięczyca, Wilkowyja i Pobitno.

Podłoże zbudowane $\mathrm{z}$ opisanych gruntów pylastych nie było w przeszłości poddane istotnym obciążeniom konsolidacyjnym, w związku z czym nie można mu przypisywać szczególnie dobrych cech wytrzymałościowych - jego nośności nie można również oceniać negatywnie. W związku z dużą porowatością może ono jednak wykazywać znaczną odkształcalność. Grunty pochodzenia eolicznego są wrażliwe na działanie wody: spływająca powierzchniowo może powodować intensywną erozję, natomiast przepływ podziemny może wywoływać niekorzystne zjawiska takie jak: sufozja, kolmatacja, w masywie mogą tworzyć się drogi uprzywilejowanej filtracji, szczeliny.

\subsection{Pradolina Podkarpacka}

W najstarszej centralnej części miasta, a także na północy oraz w dolinie Wisłoka w części południowej czwartorzędowe podłoże budują grunty akumulacji wodnej. Dominują one w dzielnicach Śródmieście, Staromieście, Miłocin, Załęże, Nowe Miasto, Drabinianka i Budziwój. W Rzeszowie wyodrębnić można nawet 3 poziomy teras zalewowych.

Najniżej w podłożu bezpośrednio na iłach mioceńskich zalegają osady o najgrubszym uziarnieniu przeważnie w postaci żwirów. Zostały one odłożone przez wody topniejącego lodowca podczas glacjału południowopolskiego. Nad nimi uformowały się nieciągłe warstwy piaszczyste, pomiędzy którymi występują liczne soczewki gruntów organicznych. Przewarstwienia torfów i namułów występują również w przypowierzchniowej, spoistej warstwie osadów rzecz- 
nych. Mady reprezentowane są przeważnie jako pyły, pyły piaszczyste, piaski gliniaste oraz średnio spoiste gliny, również gliny pylaste i gliny piaszczyste.

Należy zwrócić szczególną uwagę na liczne lokalizacje występowania gruntów słabonośnych. Są nimi grunty organiczne oraz antropogeniczne. Przewarstwienia torfów i namułów możemy spotkać na całym obszarze Pradoliny Podkarpackiej jako produkty zbiorników wodnych pozostałych po zlodowaceniu południowopolskim, jak również w późniejszych okresach efekty podwyższonych stanów wody Wisłoka lub jego mniejszych dopływów, ich starorzeczy. Pewną zawartość części organicznych można zauważyć w większości gruntów madowych na wszystkich terasach zalewowych.

\subsection{Grunty antropogeniczne}

$\mathrm{Z}$ racji tego, iż starsza zabudowa miasta zajmuje przede wszystkim teren Pradoliny Podkarpackiej tam też najczęściej spotkać można nasypy gruntów antropogenicznych. Są one efektem zarówno postępującej urbanizacji miasta, prowadzonych robót budowlanych, jak i degradacji na przestrzeni wieków naturalnych form morfologicznych - zbiorników wodnych. Likwidacja wspomnianych zbiorników często była wymuszona zmniejszaniem się z biegiem czasu atrakcyjnych terenów inwestycyjnych, często jednak było to efektem deponowania zwykłych odpadów komunalnych. Bez względu na powód i użyty do wykonywania nasypów materiał, prawdopodobieństwo, że wspomniane prace ziemne zostały wykonane w sposób uwzględniający dzisiejsze wymagania jest znikome.

$\mathrm{Na}$ nowszych osiedlach mieszkaniowych miasta zmiany ukształtowania terenu były spowodowane koniecznością zapewnienia mieszkańcom odpowiedniej infrastruktury komunikacyjnej, obiektów użyteczności publicznej oraz miejsc aktywnego wypoczynku. Takie obiekty dyskredytowały powstawanie sztucznych form morfologicznych terenu i jego niwelacji. Przeważająca część z powstających w tym czasie nasypów i wykopów była realizowana w sposób przemyślany, uwzględniający możliwości wykorzystania terenu w przyszłości.

\section{Warunki hydrologiczne}

\subsection{Wody powierzchniowe}

W związku z rozwojem zabudowy miejskiej zmianie ulegały warunki hydrologiczne na terenie Rzeszowa. Chodzi tutaj zarówno o sieć naturalnych cieków wody płynącej, jak i zbiorników wody stojącej.

Jak duże zmiany nastąpiły w tym względzie najlepiej obrazuje porównanie istniejącej zabudowy z planami Rzeszowa z 1762 r. (rys. 1.) [7], z lat 1779-1783 (rys. 2.) [8] oraz z lat 1861-1864 (rys. 3.) [9]. Na XVIII wiecznych mapach zauważyć można znaczne obszary miasta zajęte przez wody powierzchniowe. Różnice w odniesieniu do stanu obecnego są diametralne. Podobne obserwacje dotyczą także zmian koryta Wisłoka - obecna lokalizacja jego przepływu ustalona 
została na początku XX wieku $[10,11]$. Opisane zmiany stanowią najlepszy dowód nieprzewidywalności warunków gruntowych na terenie miasta, zwłaszcza w odniesieniu do obiektów posadowionych bezpośrednio.

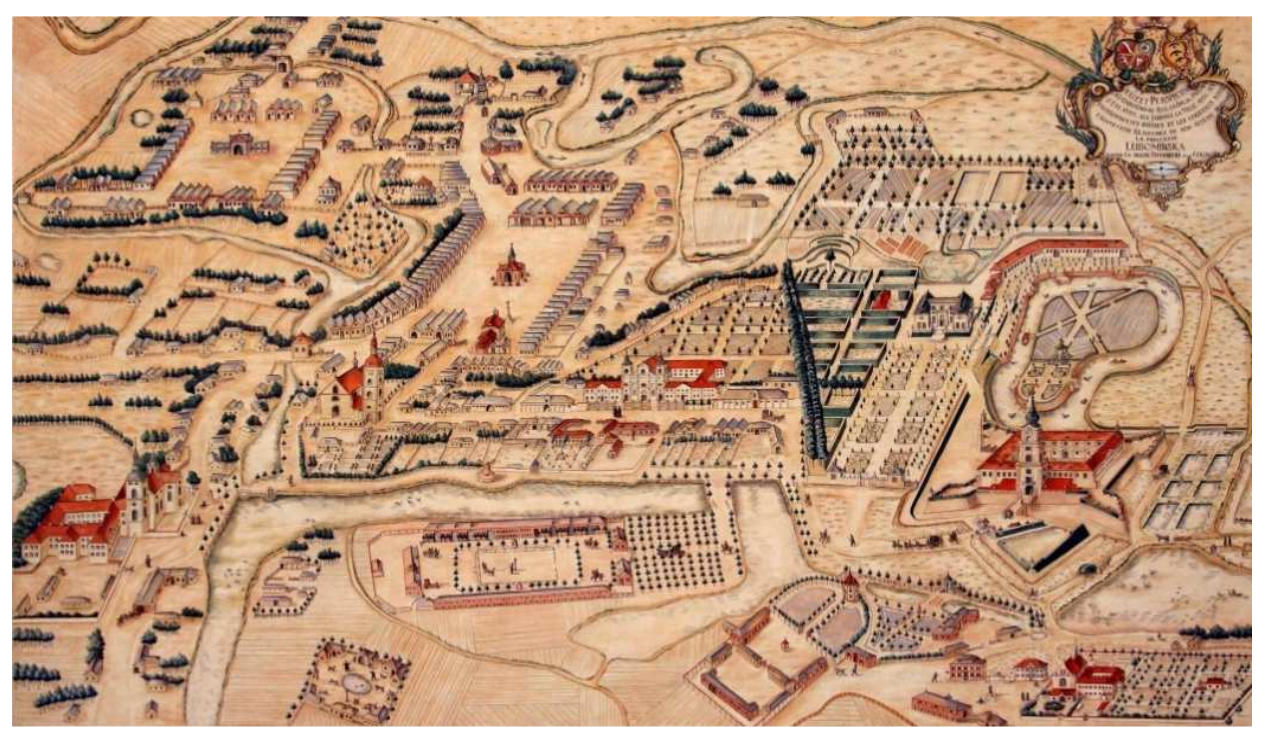

Rys. 1. Widok Rzeszowa z 1762 roku według K. H. Wiedemanna, na podstawie [7]

Fig. 1. The view Rzeszow from 1762 by K. H. Wiedemann, based on [7]

Do rozwoju każdego miasta niezbędne są nowe tereny inwestycyjne. Najbardziej pożądane to oczywiście te zlokalizowane w pobliżu centrum. Z uwagi na akumulacyjne pochodzenie podłoża w obecnej stolicy Podkarpacia ich deficyt był szczególnie widoczny. Stąd w XIX w. również na terenie Rzeszowa zaczęły się procesy osuszania soczewek stojących wód powierzchniowych oraz terenów zabagnionych. Rozpoczęto zabiegi melioracyjne i kanalizacyjne.

Prowadzone działania odniosły skutek, spływ wód został uregulowany, zmniejszyła się wilgotność podłoża. Należy pamiętać jednak, że obniżeniu zwierciadła wody towarzyszy wzrost naprężenia w gruncie, tym samym wzmożone zostały procesy konsolidacyjne w często słabym podłożu.

Potrzeby związane z zabudową miejską prowadziły do skanalizowania cieków płynących. W XX-leciu międzywojennym w swej środkowej części, przepływającej przez centrum miasta od ul. Sokoła do ul. Głowackiego przykryty został potok Mikośka. Obecnie potok ten jest skanalizowany począwszy już od ulicy Witosa. Podobna sytuacja miała miejsce później z innym lewobrzeżnym dopływem Wisłoka, potokiem Rudka, skanalizowanym od ul. Podkarpackiej.

W przeszłości w mieście prowadzone były również większe inwestycje hydrologiczne regulujące przepływ Wisłoka, z których chyba najważniejszą była zmiana przebiegu koryta - likwidacja zakola rzeki w sąsiedztwie skrzyżowania 
ulicy Chopina z ulicą Słowackiego. Inwestycja została przeprowadzona na przełomie XIX oraz XX wieku $[10,11,12]$ i była największą tego rodzaju do czasu utworzenia Zbiornika Rzeszowskiego na Wisłoku w 1973 r.

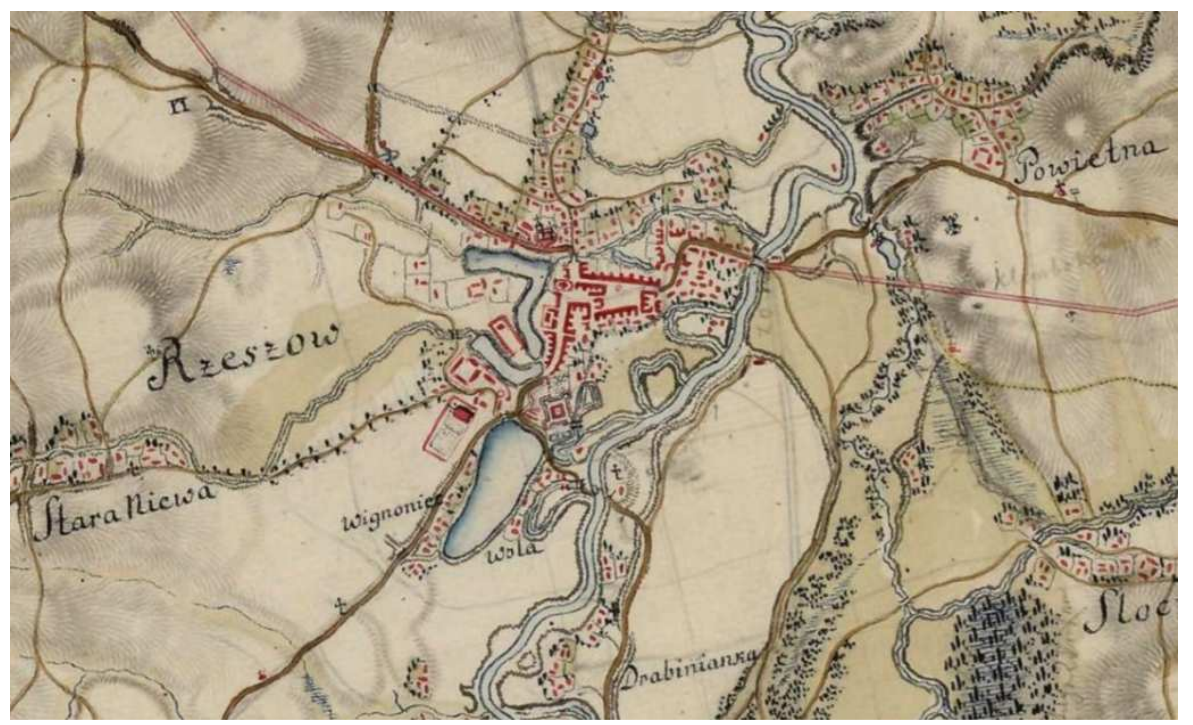

Rys. 2. Austriacka mapa Rzeszowa z lat 1779-1783, na podstawie [8]

Fig. 2. The Austrian map of Rzeszow from 1779-1783, based on [8]

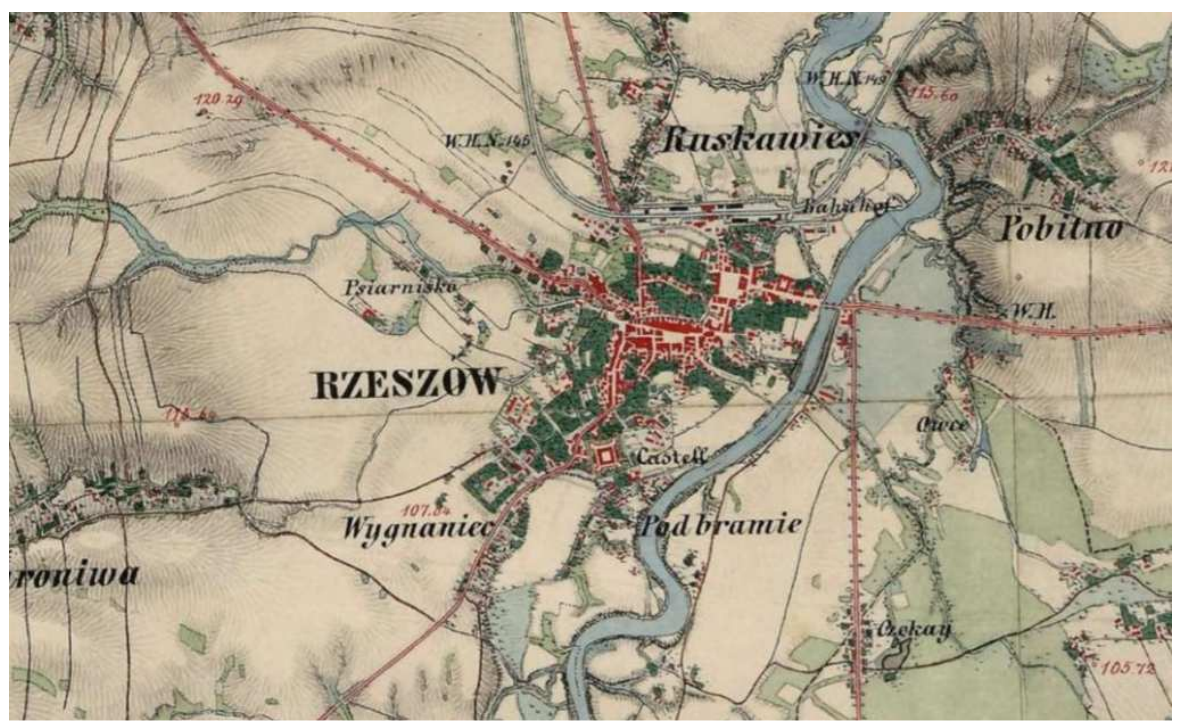

Rys. 3. Austriacka mapa Rzeszowa z lat 1861-1864, na podstawie [9]

Fig. 3. The Austrian map of Rzeszow from 1861-1864, based on [9] 


\subsection{Wody podziemne, zmiany ich poziomu oraz wpływ na warunki geotechniczne}

Wody podziemne na terenie Rzeszowa związane są z przewarstwieniami niespoistymi występującymi $\mathrm{w}$ iłach mioceńskich oraz przede wszystkim $\mathrm{w}$ warstwie piaszczysto-żwirowych osadów czwartorzędowych zdeponowanych na wspomnianych utworach spoistych. W praktyce, z punktu widzenia możliwego wpływu na posadowienie obiektów budowlanych istotny jest ich wyższy poziom (czwartorzędowy), który osiada on połączenie z wodami powierzchniowymi.

Ponieważ warstwy wodonośne przykryte są utworami spoistymi, zwierciadło wód podziemnych ma przeważnie charakter napięty. Poziom piezometryczny obniża się w sąsiedztwie cieków powierzchniowych (szczególnie Wisłoka) i wówczas może mieć charakter swobodny. Wpływ na ten stan ma również poziom wody płynącej powierzchniowo. W okresie wezbrań podnosi się także poziom wód podziemnych a odwrotne zjawisko ma miejsce w podczas suszy.

W podłożu zdominowanym przez grunty spoiste występują soczewki wody zawieszonej. Dotyczy to przewarstwień niespoistych, warstw organicznych i gruntów antropogenicznych wypełniających dawne obniżenia terenu.

Zabudowy koryt cieków nie wpłynęły bezpośrednio niekorzystnie na zabudowę miasta. Działania takie muszą jednak uwzględniać szereg zagrożeń, które mogą pojawić się po zrealizowaniu inwestycji. Dotyczą one przede wszystkim istniejących obiektów. W przypadku nowej zabudowy powinna ona zostać wzniesiona po uregulowaniu się nowych zasad przepływu wody w gruncie.

Zmiany warunków spływu wód powierzchniowych, w tym uszczelnienie koryt cieków naturalnych może stwarzać problemy i utrudniać dotychczasową filtrację w podłożu, powodując: okresowe lokalne spiętrzenia poziomu wód gruntowych, sufozję, zjawisko kolmatacji lub tworzenie szczelin, dróg uprzywilejowanej filtracji wody. Konsekwencją niektórych zakłóceń może być zintensyfikowanie destrukcyjnego działania na wody podziemne części budynku, w tym materiał, z którego są one wykonane oraz izolacje.

Wody podziemne mogą stanowić istotne zagrożenie podczas prowadzenia robót ziemnych. Ich napływ przewarstwieniami z gruntów niespoistych powodować może trudności wykonawcze przy robotach fundamentowych np. dodatkowe nakłady na odwodnienie wykopu. W przypadku wykopów znacznej głębokości, realne może być powstanie przebicia hydraulicznego (wyparcia).

\section{Zagrożenia naturalne}

\subsection{Osuwiska}

Zagrożenie naturalnymi osuwiskami w Rzeszowie jest relatywnie niewielkie. Układ warstw fliszowych, jak również postęp procesów ich wietrzenia na miejskim fragmencie Pogórza Dynowskiego nie dał do tej pory powodów do 
zaniepokojenia ruchami masowymi, które istotnie zagrażałyby infrastrukturze. Pojawiające się miejscowo osunięcia mają niewielki zasięg i są najczęściej zainicjowane przez działalność człowieka.

Na obszarze Przedgórza Rzeszowskiego stoki wzniesień zbudowanych $\mathrm{z}$ materiału pylastego nie mają dużego pochylenia. Za ruchy mas gruntowych odpowiedzialne są cieki wodne podmywające skarpy (np. ul. Konfederatów Barskich, ul. Leśna) lub celowe zmiany ukształtowania terenu (ul. Lewakowskiego).

W Pradolinie Podkarpackiej miejscami zagrożeń osuwiskowych są skarpy teras zalewowych. Inicjacja ruchów masowych może zostać wywołana przez zmiany wilgotności podłoża podczas wezbrań, zmiany warunków przepływu wód podziemnych oraz ukształtowania terenu związane z nowymi inwestycjami.

\subsection{Soczewki gruntów słabonośnych}

W związku z dużym ryzykiem występowania gruntów organicznych na terenie Pradoliny Podkarpackiej szczególną uwagę należy zwrócić na właściwe rozpoznanie podłoża gruntowego. Przypadki nawiercenia takich gruntów podczas badań terenowych są dosyć częste. To zwiększa świadomość inwestorów, co do konieczności poniesienia dodatkowych kosztów w zakresie fundamentowania. Soczewki gruntów słabonośnych zlokalizowane są na różnych głębokościach, nawet do kilkunastu metrów poniżej poziomu terenu. Od głębokości ich zalegania zależeć będzie podejście do posadowienia obiektów budowlanych. Możliwymi rozwiązaniami problemu występowania gruntów o niskich parametrach mechanicznych są: wymiana gruntu (zastosowanie poduszek piaskowych), przyspieszenie konsolidacji podłoża, posadowienie głębokie (pośrednie) obiektu, ewentualnie zwiększenie wymiarów poziomych fundamentów bezpośrednich.

Wymienione sposoby mają swoje ograniczenia, oprócz uwarunkowań technicznych, przede wszystkim finansowe.

Posadowienie bezpośrednie może być racjonalne w przypadku warstwy organicznej zalegającej na znacznej głębokości i przy jej niewielkiej miąższości. Strefa aktywna pod fundamentem może nie sięgać lub sięgać w ograniczonym zakresie do tej warstwy. Tym samym odkształcenia podłoża mogą być mało istotne dla wznoszonej budowli.

Należy zwrócić uwagę, że w większości przypadków najbardziej niebezpieczne dla budowli nie są duże wartości osiadania lecz ich znaczące różnice pomiędzy poszczególnymi częściami konstrukcji fundamentowej. Prowadzi to do wystąpienia w elementach konstrukcyjnych dużych wartości sił wewnętrznych, które jako efekty II-go rzędu nie zawsze są uwzględniane wcześniej w analizach statyczno-wytrzymałościowych. Wrażliwość konstrukcji na nierównomierne osiadania zależeć będzie od: zastosowanych schematów statycznych i rozwiązań konstrukcyjnych mających wpływ na sztywność obiektu, rozwiązań 
materiałowych oraz wartości osiadania poszczególnych części budowli z uwzględnieniem jej gabarytów.

\subsection{Grunty makroporowate}

Grunty makroporowate, w warunkach głównego miasta Podkarpacia, to grunty pochodzenia eolicznego budujące Podgórze Rzeszowskie. Jak napisano wcześniej ich struktura w porównaniu z klasycznymi lessami uległa daleko idącym zmianom i nie wykazują one cech typowo zapadowych. Niemniej jednak pod wpływem większych obciążeń wykazują one dużą ściśliwość - znacznie większą niż powszechnie przypisywana podłożu nieskonsolidowanemu.

Ta, przeważnie lekceważona cecha pylastych gruntów lessopodobnych ujawniła się szczególnie dobitnie podczas realizacji autostrady A4 oraz dróg ekspresowych, łącznikowych z istniejącą siecią komunikacyjną. Znaczna część nasypów formowanych na wspomnianym podłożu pylastym, jak również obiektów inżynierskich posadowionych w sposób bezpośredni wykazała bardzo duże osiadania, istotnie odbiegające od wartości przewidzianych przez projektantów. Wzmocnienia gruntu przewidziane w miejscach lokalizacji podpór mostów lub wiaduktów nie wystarczyły dla zatrzymania procesów konsolidacyjnych.

\section{Podsumowanie}

Warunki geotechniczne występujące na terenie Rzeszowa należy uznać za złożone i niezbyt sprzyjające postępującemu procesowi urbanizacji. Pomimo tego, proces ten wydaje się nie zwalniać swojego tempa. Opisane wcześniej, charakterystyczne czynniki warunkujące przydatność terenów zlokalizowanych w obrębie miasta na cele budowlane, stanowią z pewnością przeszkody wymagające zaangażowania większych środków finansowych.

Podłoże gruntowe w obrębie Rzeszowa cechuje swego rodzaju regionalizm, który nie zawsze jest rozumiany przez inżynierów budowlanych, zwłaszcza osoby nie mające lokalnych doświadczeń w ocenie jakości podłoża gruntowego. To „rozumienie” warunków geotechnicznych w obecnych czasach staje się coraz bardziej schematyczne, ukierunkowane na szukanie typowych rozwiązań. Takie podejście w wielu przypadkach okazuje się wadliwe, niepotrzebnie zwiększające koszty przedsięwzięć w przypadku ,przewymiarowania” fundamentów lub generujące nakłady na ich wzmocnienie jeśli „standardowe” parametry podłoża okażą się niewystarczające. W tym miejscu należy podkreślić, że kluczem do opracowania optymalnych rozwiązań posadowienia obiektów na podłożu gruntowym, zwłaszcza podłożu nie odpowiadającym powszechnie przyjętym schematom jest jego odpowiednie rozpoznanie oparte nie tylko na ustalonych zależnościach korelacyjnych, ale przede wszystkim na rzetelnych badaniach. 


\title{
Literatura
}

[1] Migoń P.: Geomorfologia, Wydawnictwo Naukowe PWN, Warszawa 2013.

[2] Mizerski W.: Geologia Polski, Wydawnictwo Naukowe PWN, Warszawa 2014.

[3] Zimnal Z., Malata T.: Objaśnienia do szczegółowej mapy geologicznej Polski, Arkusz Rzeszów (982), Państwowy Instytut Geologiczny Państwowy Instytut Badawczy, Ministerstwo Środowiska, Warszawa 2014.

[4] Zimnal Z., Malata T.: Szczegółowa mapa geologiczna Polski, Arkusz Rzeszów (982), Państwowy Instytut Geologiczny Państwowy Instytut Badawczy, Ministerstwo Środowiska, Warszawa 2014.

[5] Marciniec P., Zimnal Z.: Objaśnienia do szczegółowej mapy geologicznej Polski, Arkusz Głogów Małopolski (981), Państwowy Instytut Geologiczny Państwowy Instytut Badawczy, Ministerstwo Środowiska, Warszawa 2013.

[6] Marciniec P., Zimnal Z.: Szczegółowa mapa geologiczna Polski, Arkusz Głogów Małopolski (981), Państwowy Instytut Geologiczny Państwowy Instytut Badawczy, Ministerstwo Środowiska, Warszawa 2014.

[7] http://rzeszow.fotopolska.eu/15327,foto.html (dostęp: 24.03 .2017 r.).

[8] http://mapire.eu/en/map/firstsurvey/?bbox=2116388.4391599605\%2C6205916.205 539553\%2C2985936.072932125\%2C6582597.880928903 (dostęp: 24.03.2017 r.).

[9] http://mapire.eu/en/map/secondsurvey/?bbox=2444093.088675582\%2C6449899. 766131207\%2C2457679.7704532724\%2C6455785.417309165 (dostęp: 24.03. 2017 r.).

[10] https://maps.geshergalicia.org/cadastral/rzeszow-1888/ (dostęp: 24.03.2017 r.).

[11] https://maps.geshergalicia.org/cadastral/rzeszow-1909/ (dostęp: 24.03.2017 r.).

[12] http://rzeszow.fotopolska.eu/945895,foto.html?o=b5229\&p=1 (dostęp: 24.03. 2017 r.).

[13] https://maps.geshergalicia.org/cadastral/rzeszow-1888/ (dostęp: 24.03.2017 r.).

[14] https://maps.geshergalicia.org/cadastral/rzeszow-1909/ (dostęp: 24.03.2017 r.).

\section{GEOTECHNICAL CONDITIONS FOR BUILDINGS FOUNDATIONS IN THE RZESZOW AREA}

\begin{abstract}
S u m m a r y
The paper describes the main morphological forms occurring in the Rzeszów area, i.e. the Dynow foothills, Rzeszow submunition region and Podkarpacie ice-marginal valley. The differences in the structure of subsoil in each of these areas were indicated. The hydrological conditions in the city and their changes over time were described. These have influenced on the geotechnical conditions of the building foundations. The paper presents the natural hazards arising from the specific structure of the subsoil, which is characterized by a specific kind of regionalism. Local factors determining the geotechnical properties of the soil should be taken into account at the stage of recognition of the substrate for construction purposes.
\end{abstract}

Keywords: subsoil, groundwater conditions, Rzeszow submountain region, Podkarpacie icemarginal valley, loess similar silt, fen soil, earths, geotechnical hazards 